\title{
RUMAH MENTAWAI: AGEN PERUBAHAN MELALUI KARYA BIDANG PENDIDIKAN, KESEHATAN, SOSIAL-EKONOMI
}

\section{Williem Halim ${ }^{1}$, Amelia Kristofani ${ }^{2}$, Yustina ${ }^{3}$, Hermin Sarina ${ }^{4}$, Rafael Azarya ${ }^{5}$, Lisa Esti Puji, Tommy N. Tanumihardja, dan Herman Yosep Sutarno}

\author{
${ }^{1}$ Fakultas Teknik, Universitas Katolik Indonesia Atma Jaya Jakarta \\ Email: williemlim06@gmail.com \\ ${ }^{2}$ Fakultas Psikologi, Universitas Katolik Indonesia Atma Jaya Jakarta \\ Email: ameliakristofani27@gmail.com \\ ${ }^{3}$ Fakultas Ekonomi dan Bisnis, Universitas Katolik Indonesia Atma Jaya Jakarta \\ Email: yustina.ngatidijan@gmail.com \\ ${ }^{4}$ Fakultas Teknik, Universitas Katolik Indonesia Atma Jaya Jakarta \\ Email: sarinahermin@gmail.com
}

\begin{abstract}
Indonesia has a lot of natural beauty that is unmatched. One of the great panoramas in Indonesia is the Mentawai Islands. Natural beauty is complemented by abundant natural resources making this area a place that has great potential for growth. Unfortunately, not all communities have the desire and ability to manage natural resources properly. Seeing the potential possessed by the Mentawai, the Association of Indonesian Catholic Colleges (APTIK) was moved to implement the Kuliah Kerja Nyata (KKN) APTIK Mentawai care program. The KKN APTIK Cares Mentawai activities have reached the fifth wave held on 1 - 31 July 2019. Where this activity aims to develop the Mentawai Islands region to be better by developing the existing potential. There were five students who were sent as delegates from Atma Jaya University. The five students were divided into seven different hamlets together with students from other universities. The students carry out the 3 pillars of the program namely, education: home learning, building faith and teaching in formal schools, socio-economics: production and marketing of products, and health: clean and healthy life. Mentawai people are expected to be able to develop these 3 fields independently going forward. This activity made students aware that the knowledge they learned in their lectures could be applied to something more noble, namely by applying this knowledge to develop and make changes in society, especially Mentawai.
\end{abstract}

Keywords: Agent of change; Potency; KKN; Natural resources

Indonesia mempunyai banyak keindahan alam yang tidak tertandingi. Salah satu panorama hebat yang ada di Indonesia adalah Kepulauan Mentawai. Keindahan alam dilengkapi dengan sumber daya alam yang melimpah menjadikan daerah ini sebagai tempat yang memiliki potensi besar untuk berkembang. Sayangnya, tidak semua masyarakat memiliki keinginan dan kemampuan untuk mengelola sumber daya alam dengan baik. Melihat potensi yang dimiliki oleh Mentawai, Asosiasi Perguruan Tinggi Katolik Indonesia (APTIK) tergerak untuk melaksanakan program Kuliah Kerja Nyata (KKN) APTIK Peduli Mentawai. Kegiatan KKN APTIK Peduli Mentawai telah mencapai gelombang kelima yang diadakan pada 1 - 31 Juli 2019. Dimana kegiatan ini bertujuan untuk membangun daerah Kepulauan Mentawai menjadi lebih baik dengan mengembangkan potensi yang ada. Terdapat lima orang mahasiswa yang diutus menjadi delegasi dari Unika Atma Jaya. Kelima mahasiswa tersebut dipecah kedalam tujuh dusun berbeda bersama dengan mahasiswa dari universitas lain. Para mahasiswa melaksanakan 3 pilar program yaitu, pendidikan: rumah belajar, bina iman dan mengajar di sekolah formal, sosial-ekonomi: produksi dan pemasaran produk, dan kesehatan: hidup bersih dan sehat. Masyarakat Mentawai diharapkan mampu mengembangkan 3 bidang tersebut secara mandiri kedepannya. Kegiatan ini menyadarkan mahasiswa bahwa ilmu yang mereka pelajari dibangku perkuliahan dapat diaplikasikan untuk hal yang lebih mulia, yaitu dengan mengaplikasikan ilmu tersebut untuk mengembangkan dan membuat perubahan di masyarakat, khususnya Mentawai.

Kata kunci: Agen Perubahan, Potensi, KKN, Sumber Daya Alam

\section{PENDAHULUAN}

Indonesia mempunyai banyak keindahan alam yang tidak tertandingi. Salah satu panorama hebat yang ada di Indonesia adalah Kepulauan Mentawai. Keindahan alam dilengkapi dengan sumber daya alam yang melimpah menjadikan daerah ini sebagai tempat yang memiliki potensi besar untuk berkembang. Sayangnya, tidak semua masyarakat memiliki keinginan dan kemampuan untuk mengelola sumber daya alam dengan baik. 
Desa Katurai sendiri sebetulnya memiliki sumber daya alam yang cukup melimpah dan beraneka ragam, baik sumber daya lahan/ darat maupun sumber daya laut. Namun, sumber daya alam di daerah ini tampaknya belum dimanfaatkan secara optimal. Salah satu faktor rendahnya pemanfaatan sumber daya alam di daerah ini adalah belum berkembangnya kegiatan ekonomi, sebagai akibat masih minimnya sarana prasarana serta kondisi keterisolasian yang menyebabkan daerah ini tertinggal dalam proses pembangunan.

Melihat potensi yang dimiliki oleh Mentawai, Asosiasi Perguruan Tinggi Katolik Indonesia (APTIK) tergerak untuk melaksanakan program Kuliah Kerja Nyata (KKN) APTIK Peduli Mentawai. Awal mula, Keterlibatan APTIK dalam pembangunan masyarakat Kabupaten Kepulauan Mentawai dimulai sejak tahun 2014, ketika Bupati Kepulauan Mentawai, Bapak Judas Sabalagot, menyampaikan permasalahan yang dihadapi daerahnya di depan Forum Rektor dalam Rapat Umum Anggota (RUA) APTIK di Palembang, dalam bulan Maret 2014. Setelah itu, pada hari Jumat, 9 November 2018 bertempat di Muara Siberut, dalam forum Lokakarya Pembangunan Masyarakat Mentawai yang diadakan oleh APTIK bekerjasama dengan Keuskupan Padang, telah menghasilkan rekomendasi, yaitu mendukung pemerintah dalam memfasilitasi pelatihan aneka keterampilan dalam bidang pendidikan kewirausahaan dan tetap menyelenggarakan KKN APTIK Peduli Mentawai.

Selain itu keadaan pendidikan masyarakat Mentawai, khususnya di Desa Katurai sangat rendah, dengan melihat jumlah masyarakat terdidik yang tamat SD sekitar 37,7\% berdasarkan penelitian yang dilakukan oleh LIPI pada tahun 2017. Padahal seharusnya, menurut teori fungsionalisme (sumber: Usman, 2004), dimana teori ini mengandaikan komunitas masyarakat sebagai satu sistem tubuh manusia. organ-organ dalam tubuh manusia harus fungsional dalam bergerak dan berdinamika untuk mencapai satu tubuh yang sehat. Begitu juga dengan masyarakat, dimana didalamnya terdapat lembaga-lembaga sosial sebagai interpretasi dari organ-organ masyarakat. Masing-masing lembaga tersebut memiliki peran dan fungsi berbeda, yang perlu berlanjut mengikuti fungsinya. Dalam perjalanannya, bagian-bagian dari suatu sistem masyarakat bisa berkembang pada tiga kemungkinan; fungsional, disfungsional, dan non-fungsional.

Dalam hal ini, bidang pendidikan yang ada di Desa Katurei merupakan satu lembaga dalam sistem masyarakat mentawai yang tidak menjalankan fungsinya dengan baik atau disfungsional. Hal ini mengakibatkan munculnya berbagai macam permasalahan lainnya yang disebabkan oleh rendahnya tingkat pendidikan masyarakat Katurei. Berangkat dari masalah ini, APTIK juga ikut turut serta menyelesaikan masalah pendidikan, dengan memberikan program beasiswa kuliah, dan juga melalui program kuliah kerja nyata khususnya melalui program pendidikan formal, non-formal, dan bina iman anak.

Kegiatan KKN APTIK Peduli Mentawai telah mencapai pada gelombang kelima. Dimana gelombang kelima ini merupakan $\mathrm{KKN}$ penutup dan terakhir dari serangkaian KKN yang dilaksanakan sebelumnya di desa Katurei. Dimulai dari gelombang pertama dan kedua dengan fokus untuk observasi wilayah, gelombang ketiga dengan fokus pengembangan wawasan masyarakat Mentawai dalam pengolahan bahan pangan lokal, gelombang keempat dengan fokus pelatihan pengemasan olahan produk dengan bahan pangan lokal dan gelombang kelima yang berfokus pada pengemasan dan pemasaran produk bahan pangan lokal. Penyelenggaraan kegiatan KKN - APM ini bertujuan untuk: Mengembangkan kepribadian, kepekaan sosial dan kemampuan kepemimpinan mahasiswa dan memberikan pendampingan kepada masyarakat, gereja, dan pemerintah Kabupaten Kepulauan Mentawai dalam meningkatkan kesejahteraan masyarakat.

\section{METODE KEGIATAN}

Metode yang digunakan dalam kegiatan ini adalah metode Etnografi. Etnografi berasal dari bahasaYunani, ethnos yang berarti orang dan graphein yang berarti tulisan. Etnografi ini bisa digunakan untuk mempelajari masyarakat, kelompok etnis dan juga budaya material dan spiritual mereka. Spradley (1997) mengungkapkan langkah langkah penelitian etnografi harus diawali dengan menentukan lokasi penelitian. Menurut Spradley tanpa penentuan lokasi yang jelas kerja etnografi mustahil dilakukan. 
Dalam hal ini kami menggunakan metode Etnografi untuk meneliti masyarakat yang ada Desa Katurai, Kecamatan Siberut Barat Daya, Kepulauan Mentawai, Sumatera Barat dan melakukan pengumpulan data dengan cara Live In yang berlangsung pada tanggal 1 Juli 2019 - 31 Juli 2019. Dengan kegiatan live in kami bisa untuk mengobservasi masyarakat secara langsung dan mengumpulkan data.

Mahasiswa anggota APTIK tinggal bersama dengan masyarakat selama sebulan di Desa Katurai, Kecamatan Siberut Barat Daya, Kepulauan Mentawai. Dalam pelaksanaannya selama sebulan tersebut, dibagi menjadi tiga tahap yaitu, tahap perencanaan, pelaksanaan, dan evaluasi dan refleksi. Berikut adalah penjelasan lebih lanjut masing-masing tahap :

Pada Tahap Perencanaan mahasiswa akan mengumpulkan informasi awal tentang potensi dan permasalahan yang dihadapi masyarakat, dan melakukan analisis sosial untuk memahami konteks kehidupan masyarakat dimana ia ditugaskan. Berdasarkan hasil analisis sosial tersebut, mahasiswa merencanakan serangkaian kegiatan (program kerja) yang akan dilakukan selama berada ditengah masyarakat tersebut.

Pada Tahap Pelaksanaan, mahasiswa akan melakukan berbagai kegiatan meliputi interaksi sosial bersama masyarakat (anak-anak, kaum muda, orang tua, tokoh masyarakat) dalam kehidupan sehari-hari, pengamatan lebih lanjut terhadap adat kebiasaan setempat, pertemuan bersama kelompok masyarakat, sumbangan pemikiran untuk kemajuan masyarakat setempat, serta kegiatan fisik (proyek) yang dilakukan bersama masyarakat.

Pada Tahap Evaluasi dan Refleksi, para mahasiswa akan melakukan evaluasi atas keberhasilan dan kegagalan dalam pelaksanaan rencana yang telah mereka susun sebelumnya, memberikan rekomendasi untuk perbaikan ke depan, dan melalui refleksi pribadi mereka akan memberi makna atas pengalaman hidup yang mereka peroleh bersama masyarakat. Kegiatan ini merupakan kegiatan yang sudah berkelanjutan dan pendanaan dari eksternal menandakan bahwa kegiatan ini sudah melalui proses review yang cukup baik. Kedepannya kegiatan ini akan terus dilanjutkan dan ditingkatkan pada batch-batch berikutnya.

\section{HASIL DAN PEMBAHASAN}

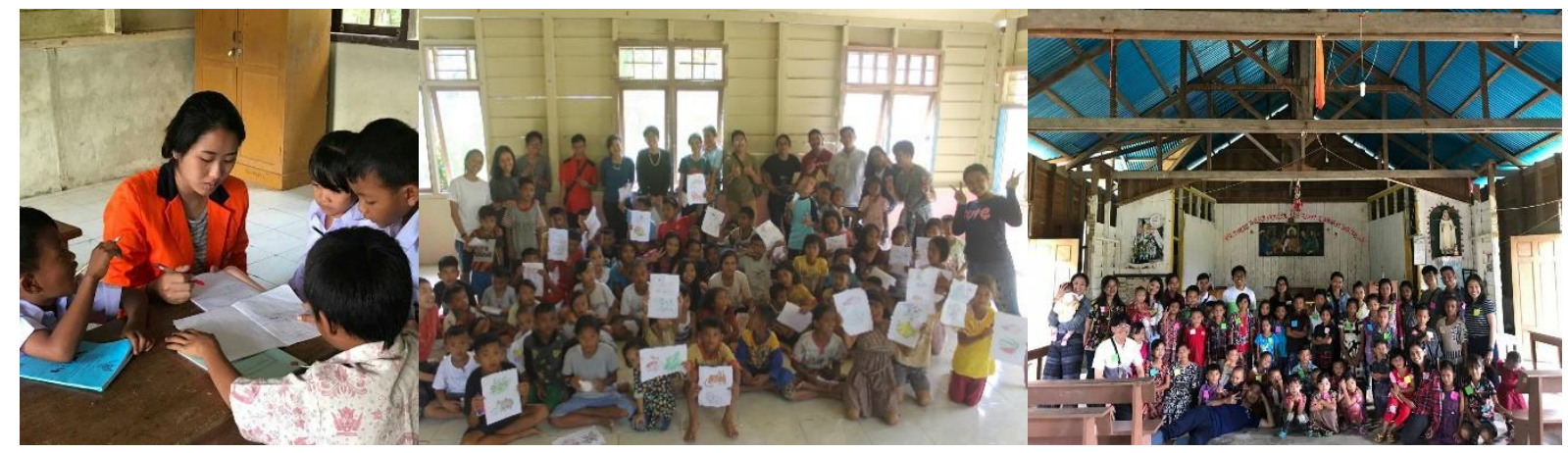

Gambar 1. Hasil Kegiatan Bidang Pendidikan 
Tabel 1. Perbedaan Sebelum dan Sesudah Pelatihan

\begin{tabular}{|c|c|c|c|c|}
\hline No. & Bidang & Kegiatan & Sebelum & Sesudah \\
\hline \multirow{5}{*}{1.} & \multirow{5}{*}{ Pendidikan } & \multirow[t]{2}{*}{ Sekolah Formal } & Sistem pembelajaran monoton & $\begin{array}{l}\text { Sistem pembelajaran lebih } \\
\text { bervariasi, karena menggunakan } \\
\text { media pembelajaran seperti } \\
\text { flashcard, poster dan } \\
\text { mengkombinasikan bermain sambil } \\
\text { belajar }\end{array}$ \\
\hline & & & $\begin{array}{l}\text { Anak-anak kelas } 1 \text { - } 3 \text { SD tidak } \\
\text { mengetahui kosakata bahasa } \\
\text { Inggris }\end{array}$ & $\begin{array}{l}\text { Anak-anak kelas } 1 \text { - } 3 \text { SD mampu } \\
\text { menghafal dan melafalkan } 10 \\
\text { kosakata bahasa inggris }\end{array}$ \\
\hline & & & $\begin{array}{l}\text { Kegiatan rumah belajar tidak } \\
\text { rutin diadakan }\end{array}$ & $\begin{array}{l}\text { Kegiatan rumah belajar rutin } \\
\text { diadakan setiap minggunya }\end{array}$ \\
\hline & & Rumah Belajar & $\begin{array}{l}\text { Anak-anak hanya mengetahui } \\
\text { profesi guru, polisi dan tentara }\end{array}$ & $\begin{array}{l}\text { Anak-anak mengetahui profesi baru, } \\
\text { seperti pilot, pemain bola, pemadam } \\
\text { kebakaran, dokter, atlet, dan petani }\end{array}$ \\
\hline & & $\begin{array}{l}\text { BIAK (Bina Iman } \\
\text { Anak Katolik) }\end{array}$ & $\begin{array}{l}\text { Kegiatan BIAK sempat tidak } \\
\text { berjalan, sehingga anak-anak } \\
\text { tidak memiliki wadah untuk } \\
\text { kegiatan sekolah Minggu }\end{array}$ & $\begin{array}{l}\text { Kegiatan BIAK aktif kembali setiap } \\
\text { minggunya }\end{array}$ \\
\hline \multirow{4}{*}{2.} & \multirow{4}{*}{ Kesehatan } & $\begin{array}{l}\text { Pengecekan Golongan } \\
\text { Darah }\end{array}$ & $\begin{array}{l}\text { Sebagian besar masyarakat } \\
\text { tidak mengetahui golongan } \\
\text { darahnya masing-masing }\end{array}$ & $\begin{array}{l}\text { Sebagian besar masyarakat } \\
\text { mengetahui golongan darahnya } \\
\text { masing-masing }\end{array}$ \\
\hline & & $\begin{array}{l}\text { Pembuatan WC } \\
\text { Umum }\end{array}$ & $\begin{array}{l}\text { Masyarakat Dusun Tiop tidak } \\
\text { memiliki WC umum }\end{array}$ & $\begin{array}{l}\text { Masyarakat Dusun Tiop memiliki } 2 \\
\text { buah WC Umum }\end{array}$ \\
\hline & & $\begin{array}{l}\text { Hidup Bersih dan } \\
\text { Sehat }\end{array}$ & $\begin{array}{l}\text { Anak-anak tidak mengetahui } \\
\text { cara mencuci tangan dan sikat } \\
\text { gigi yang benar }\end{array}$ & $\begin{array}{l}\text { Anak-anak mulai mengetahui cara } \\
\text { mencuci tangan dan sikat gigi yang } \\
\text { benar }\end{array}$ \\
\hline & & $\begin{array}{l}\text { Pembuatan Tempat } \\
\text { Sampah dan Tempat } \\
\text { Pembuangan Akhir }\end{array}$ & $\begin{array}{l}\text { Masyarakat membuang sampah } \\
\text { sembarangan }\end{array}$ & $\begin{array}{l}\text { Masyarakat mulai membuang } \\
\text { sampah pada tempat sampah dan } \\
\text { membakar sampah }\end{array}$ \\
\hline \multirow{4}{*}{3.} & \multirow{4}{*}{$\begin{array}{l}\text { Sosial } \\
\text { Ekonomi }\end{array}$} & $\begin{array}{l}\text { Produksi dodol kojo, } \\
\text { keripik pisang, keripik } \\
\text { ubi, abon, dan } \\
\text { kerupuk ikan }\end{array}$ & $\begin{array}{l}\text { Belum melakukan produksi } \\
\text { rutin }\end{array}$ & $\begin{array}{l}\text { Mulai mengadakan produksi rutin } \\
\text { per minggu }\end{array}$ \\
\hline & & Kemasan & $\begin{array}{l}\text { Mengemas produk dengan } \\
\text { menggunakan lilin }\end{array}$ & $\begin{array}{l}\text { Mengemas produk dengan } \\
\text { menggunakan sealler }\end{array}$ \\
\hline & & Kanal & $\begin{array}{l}\text { Mulut ke mulut dan warung di } \\
\text { dusun }\end{array}$ & $\begin{array}{l}\text { Mulut ke mulut, warung di dusun, } \\
\text { dan mampu menjual ke Muara di } \\
\text { pulau sebrang }\end{array}$ \\
\hline & & $\begin{array}{l}\text { Pembuatan Lampu } \\
\text { Jalan }\end{array}$ & $\begin{array}{l}\text { Belum memiliki lampu jalan } \\
\text { sebagai penerangan }\end{array}$ & $\begin{array}{l}\text { Memiliki lampu jalan yang tersebar } \\
\text { di } 10 \text { titik sebagai penerangan }\end{array}$ \\
\hline
\end{tabular}

Pada setiap gelombangnya kegiatan KKN yang dilakukan memiliki kesamaan tujuan, yaitu untuk membangun daerah Kepulauan Mentawai, menjadi lebih baik dan mengembangkan potensi yang dimiliki oleh daerah Kepulauan Mentawai. Dimulai dari gelombang pertama dan kedua dengan fokus untuk observasi wilayah, gelombang ketiga dengan fokus pengembangan wawasan masyarakat Mentawai dalam pengolahan bahan pangan lokal, gelombang keempat dengan fokus 
pelatihan pengemasan olahan produk dengan bahan pangan lokal dan gelombang kelima yang berfokus pada pengemasan dan pemasaran produk bahan pangan lokal.

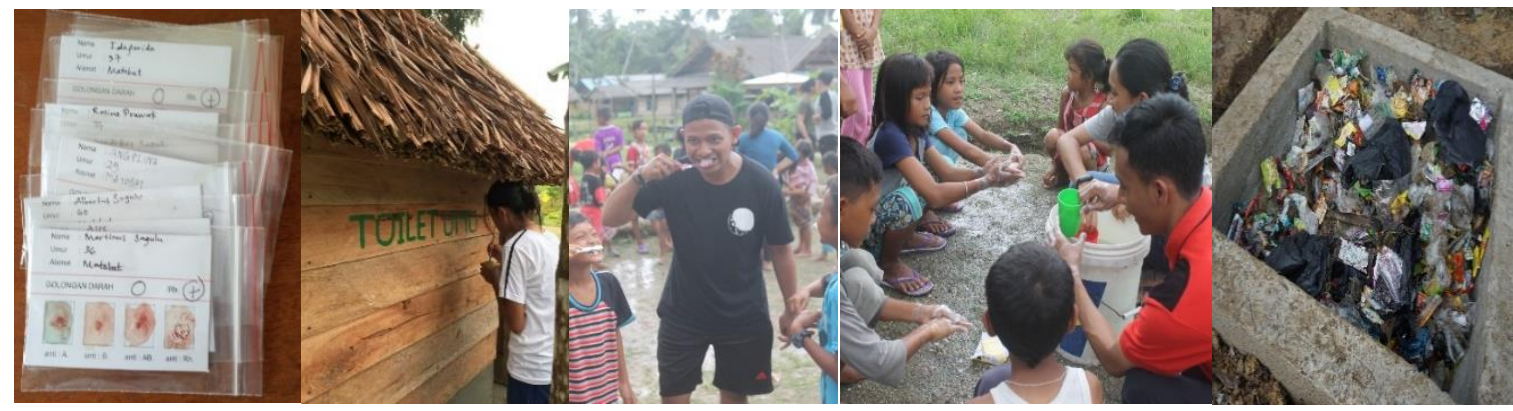

Gambar 2. Hasil Kegiatan Bidang Kesehatan

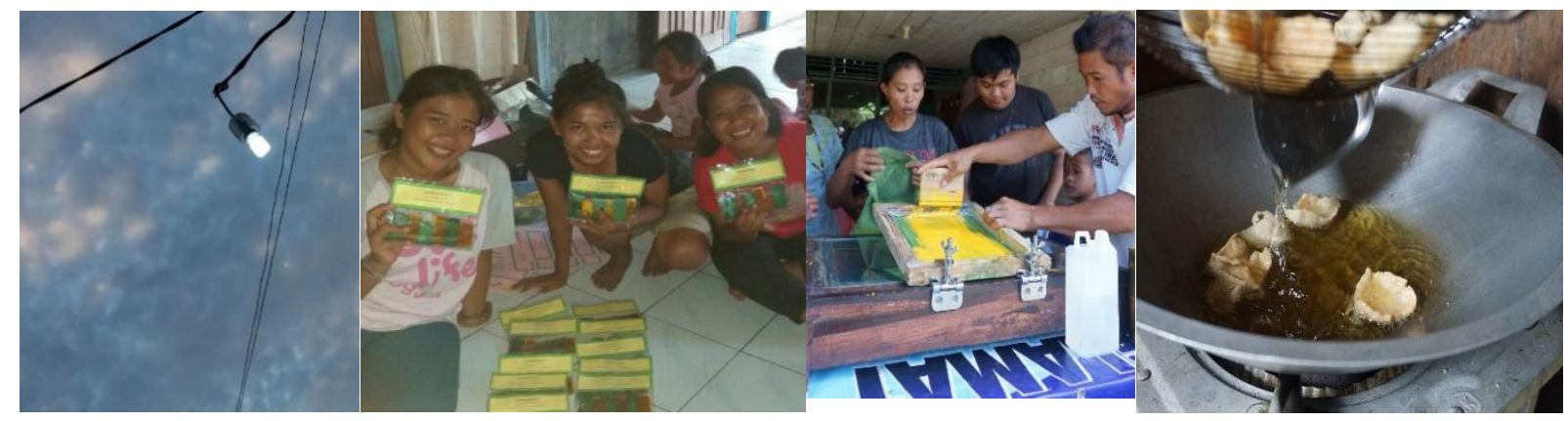

Gambar 3. Hasil Kegiatan Bidang Sosial-Ekonomi

Pada KKN Gelombang 5 terdapat 3 bidang yang menjadi fokus utama untuk dikembangkan, yaitu bidang Pendidikan, Kesehatan dan Sosial-Ekonomi. Akan tetapi yang menjadi fokus utama ialah mengenai pengemasan dan pemasaran bahan pangan lokal. Dimana diharapkan masyarakat Mentawai, mampu mandiri pada tiga bidang tersebut. Pada bidang pendidikan, terdapat tiga kegiatan yang dilakukan dalam pemberdayaan masyarakat, khususnya anak-anak, yaitu kegiatan sekolah formal, rumah belajar dan BIAK. Melalui kegiatan di bidang pendidikan yang telah dilakukan terdapat perubahan yang terjadi khususnya pada anak-anak, diantaranya adalah anak-anak memiliki sarana dan wadah untuk belajar dan mendapatkan pengetahuan dan ilmu baru. Pada bidang kesehatan juga terdapat suatu perubahan di masyarakat, dimana masyarakat yang semulai tidak mengetahui golongan darahnya, saat ini sudah mengetahui hal tersebut, disamping itu masyarakat lebih peduli tentang sanitasi, lebih peduli pada lingkungan dengan mulai membuang sampah pada tempatnya serta lebih peduli hidup bersih dan sehat. Pada bidang sosial-ekonomi, masyarakat saat ini mulai sadar untuk lebih memanfaatkan bahan pangan lokal seperti pisang, ubi dan buah kojo menjadi sumber penghasilan. Selain itu masyarakat, khususnya ibu-ibu mulai menjual produk dengan kemasan yang lebih baik dan layak, serta memiliki packaging, sehingga produk olahan dusun mulai bisa dijajakan di luar dusun, yaitu di Muara. Melalui kegiatan ini para mahasiswa juga belajar bahwa dalam merubah suatu masyarakat, semua harus dimulai dari diri sendiri, dan tidak memerlukan suatu perbuatan besar. Tetapi menjadi agen perubahan sosial bisa dilakukan melalui perbuatan yang sederhana tapi bisa memberikan dampak yang baik di tengah masyarakat. Sehingga masyarakat menjadi sadar akan pentingnya suatu perubahan di dalam masyarakat. 


\section{SIMPULAN DAN SARAN}

KKN APTIK peduli Mentawai Batch ke- 5 merupakan gelombang terakhir sebagai penutupan 5 tahun abdi Asosiasi Perguruan Tinggi Katolik Indonesia kepada pemberdayaan masyarakat desa Katurai, Kepulauan Mentawai,. Kegiatan yang dilaksanakan 1 bulan pada Bulan Juli 2019 terpatnya pada Desa Katurei ini membawa 3 pilar program utama yaitu Pendidikan (Sekolah Formal, Rumah Belajar, Bina Iman Anak), Kesehatan (Pengecekan Golongan Darah, Pembuatan WC Umum, Pembuatan Tempah Sampah dan TPA, Hidup Bersih dan Sehat), dan Sosial Ekonomi (Pembuatan Dodol Kojo dan Keripik Pisang, Kemasan, Kanal, dan Pembuatan Lampu Jalan). Ketiga program ini dilaksanakan oleh Mahasiswa utusan Universitas dan dalam pengerjaannya, dipecah kedalam 7 Dusun yang berbeda.

\section{Ucapan Terima Kasih}

Ucapan terimakasih kepada misereor dari Jerman yang telah mendanai kegiatan KKN gelombang kelima, dan APTIK selaku penyelenggara kegiatan KKN Aptik Peduli Mentawai, serta koordinasi dari dosen-dosen perutusan setiap Universitas Katolik Indonesia yang tergabung dalam program ini, terkhusus dosen pembimbing Unika Atma Jaya Jakarta yang telah memberikan pembekalan yang mengumpuni sebelum terjun ke lapangan. Kerjasama tim antar universitas, bantuan tempat tinggal dari Paroki di Muara Siberut, serta semua kepala desa dan masyarakat yang aktif membantu sosialisasi hingga susksesnya program kami, kami ucapkan terimakasih.

\section{REFERENSI}

Kamarusdiana. (2019). Studi Etnografi Dalam Kerangka Masyarakat dan Budaya. Jurnal Sosial dan Budaya Syar-1, Vol 6, No 2.

Usman, S. (2004). Sosisologi: Sejarah, Teori dan Metodologi. Yogyakarta: Cired

Astuti dan Utami Devi.(2018).Perencanaan Pembangunan Berkelanjutan di Desa Putat Kecamatan Patuk Kabupaten Gunungkidul.

Istiyanto dan Wiwik Novianti.(2018). Etnografi Komunikasi yang Kehilangan Identitas Sosial dan Budaya di Kabupaten Cilacap. Jurnal kajian komunikasi,Vol 6,No 1.

Istiyanto.(2014). Membangun Identitas di antara Dua Budaya.

Lutfiyah dan Eni Winaryati. (2017). Pengaruh Kompetensi Sosial Guru Terhadap Hasil Belajar Siswa (Di SMA Muhamadiyah 1 Semarang) 